\title{
$114:$ 認知動作型トレーニングが発育期の少年の走力に及ぼす影響
}

館 俊樹 所属 : 静岡県総合健康センター

共同研究者：久保田晃生、井本岳秋、鈴鹿和子、藤田信（静岡県総合健康センター） 小林寛道（東京大学大学院）

キーワード: 青少年、体力

緒言：青少年の体力低下は高齢者の ADL の低下とともに重要な社会課題として認知されている。特に 積極的に運動を行い、運動自体が好きだという子供と運動を好まず、運動に対する自信があまりない 子供の二極化が拡大してきている傾向にあるという報告が多く見られる。そこで、今回の発表では多 くのの運動にかかわる走動作を向上させることで青少年の体力低下を抑制することを試みた。本研究 では体幹深部機能を向上させると考えられている認知動作型トレーニング機器を使用することで走能 力の向上を目指した。

方法 : 2005 年 6 月 25 日に行われた静岡県三島市周辺の小学生を対象に行った「親子認知動作型運動 教室」前後に $50 \mathrm{~m}$ 走のタイム測定を行った。

結果と考察 : 今回の教室では 1 日という短期間の間にトレーニングと測定の両方を行ったため疲労に よる影響からタイムの向上が望めないと考えられた。また、一般に全力 $50 \mathrm{~m}$ 走の繰り返しによるタイ ム低下は広く知られており本教室においても同様の結果が予想された。しかし、本教室ではタイムの 向上こそ見られなかったものの、教室開始前と教室後のタイムの間に変化はなかった。このことは、 疲労による影響を取り除いた場合タイムの向上が見られたのではないかと期待される。また、疲労の 疲労を比較的受けづらいスタートから $10 \mathrm{~m}$ までのタイムには有意な向上がみられた。このことから、 認知動作型トレーニングを行うことで短期間のトレーニングであっても走力の向上させる可能性が示 唆された。

$(メ モ)$ 